\title{
Diet composition and habitat use of sympatric polecat and American mink in western France
}

\author{
Thierry LODÉ
}

Lodé T. 1993. Diet composition and habitat use of sympatric polecat and American mink in western France. Acta theriol. 38: 161 - 166.

Food habits of European polecat Mustela putorius Linnaeus, 1758 and of American mink Mustela vison Schreber, 1777 are compared by analysis of scats collected from two radiotracked animals in a marsh habitat over a 5 month period. Both predators take a wide range of prey but polecat consumes more rodents and feeds upon amphibians in spring, whereas mink mainly preys on fish and birds. Dietary overlap results from the common utilization of rodent prey. Both predators reduce competition by intensive exploitation of different resources and by segregation in the space use.

Laboratoire d'Ethologie, Université de Rennes 1, 35042 Rennes, France

Key words: Mustela putorius, Mustela vison, food niche overlap, telemetry

\section{Introduction}

Coexistence and competition within mustelid communities have been discussed extensively by Rosenzweig 1966, Powell and Zielinski 1983, and Moors 1984, particularly for the genus Mustela where dietary overlap is marked. European polecat Mustela putorius Linnaeus, 1758 usually frequents the wetlands in western France (Lodé 1990) which feral American mink Mustela vison Schreber, 1777 has been colonizing for some years (Saint-Girons et al. 1988). Nevertheless, knowledge of the food of feral mink includes only a few recent studies in France (Lodé et al. 1990 ) and the potential impact of mink on the native carnivore fauna is unknown. American mink may compete notably with European mink Mustela lutreola, otter Lutra lutra and polecat which all live in similar habitat. Competitive interactions could be all the more important because the predator sizes are not different. The diet of American mink and otter have been described in Sweden, Scotland and England (Erlinge 1972, Jenkins and Harper 1980, Chanin 1981, Wise et al. 1981). Several authors agree that European mink and feral American mink could be competitors (Aliev and Sanderson 1970, Chanudet and Saint-Girons 1981, Yougman 1982, Sidorovich 1992), but little is known about the food competition between them.

This study attempts to assess competition between American mink and polecat by describing their diet and movements in a marsh area. 


\section{Study area}

Data were collected in Grande Brière marshes along the French west coast $\left(47^{\circ} 28^{\prime} \mathrm{N}, 2^{\circ} 15^{\top} \mathrm{W}\right)$. Grande Brière marshes covers $67 \mathrm{~km}^{2}$ and was designated the Brière Regional Natural Park in 1971. Plant communities consist mainly of Carex and Typha, but the natural flooded grassland have become more and more invaded by reeds (Dupont 1972). Marshes are bordered by wooded formland hedged by Salix, Carpinus, and Quercus with Crataegus and Sambucus. Fish fauna is dominated by eels Anguilla anguilla, cyprinids and cat fish Ictalurus meles. The wetland is used by several species of sedentary and migratory waterfowl. Other carnivores present are foxes Vulpes vulpes, weasels Mustela nivalis, stoats Mustela erminea, and otters Lutra lutra.

\section{Material and methods}

A resident male polecat was radiotracked between 27 november 1990 and 9 April 1991. A male American mink was radiotracked on the same area between 20 December 1990 and 10 March 1991. Both mustelids were live-trapped and fitted with radiotransmitters (see Zimmerman et al. 1976). The animals were repeteadly located by triangulation using a portable receiver and an hand-held antenna, in periods of $6 \mathrm{~h}$ per night with a location on each animal every $45 \mathrm{~min}$, but some intensive trackings were carried out with a fix every $10 \mathrm{~min}$. Most locations were recorded at night, while mustelids were active but at least three fixes were collected during daytime. Each location was centered on a $50 \mathrm{~m}$ grid (see Lode 1993). Noticed that the mustelids were often very noisy when they foraged and were very easy to locate. Following movements of the animals at night, it was possible to make a daily search for scats. Because the animals did not frequent the same area at the same time, the faeces were easely discriminated. The fresh faeces which were found on each predator's path (or near the den) were reported to the surveyed animal. Because we concentrated the daily search for scats on each mustelid's path, and we collected only fresh faeces, the probability of a confusion with another individuals was extremely low. The faeces were measured (mean diameter $0,9 \mathrm{~cm}$ ), weighted and stored dry before analysis. There were collected 108 polecat and 84 mink scats.

Identification of prey depends on the indigestible remains in the faeces. Hair was identified by colour, form and microscopical sections in comparison with a reference collection and the photographs (Day 1966, Debrot et al. 1982). Teeth and bones also assisted the determination (Chaline et al. 1974). Amphibians bones were identified by comparison with a reference collection and with Rage (1974). Scales, pharyngeal bones and vertebraes were used in the identification of fish (Camby et al. 1984). Another difficulty arises with the presence of earthworms and arthropods in faeces which either originated from fish, amphibians and shrews, or were directly ingested. Remains of invertebrates composing less than $10 \%$ of the scat volume were discarded.

Percentage frequency of occurrence was used to present dietary composition. Based on climatic change, it was considered three periods: (1) from 27 November to 31 December - a mild period here called autumn (mean temperature $5.6^{\circ} \mathrm{C}$, deficient precipitations, 2 freezing days), (2) from 1 January to 20 February - a cold and humid period called winter (mean temperature $2^{\circ} \mathrm{C}, 22$ freezing days), (3) from 20 February to 9 April - a rise in temperature period (mean $7^{\circ} \mathrm{C}$, no freezing day) called spring. Niche overlap is calculated according to Schoener (1971) $\mathrm{C}_{\mathrm{jk}}=1-0.5 \Sigma\left(\mathrm{Pi}_{\mathrm{j}}-\mathrm{Pi}_{\mathrm{k}}\right)$, where $\mathrm{Pi}_{\mathrm{j}}$ and $\mathrm{Pi}_{\mathrm{k}}$ are the proportions of a food category $(\%)$ in the diet of predators and the proportions of used habitats. The $\mathrm{C}_{\mathrm{jk}}$ index varies from 0 (niches isolation) to 1 (identity). The Shannon index $H^{\prime}=-\Sigma \mathrm{p}_{\mathrm{i}} \log \mathrm{p}_{\mathrm{i}}$, where $p_{i}$ is a food category proportion, was calculated, based on mammals, birds, amphibians, fish and invertebrates. 


\section{Results and discussion}

\section{Habitat utilization}

We obtain 306 radiolocations for the male polecat and 190 for the male mink (Fig. 1). The space is not uniformly used by both predators and the activity of the animals was concentrated on very restricted areas. This particular spacing pattern is considered at the expression of an intensive exploitation of a single resource (Weber 1989b, Lodé 1991a, b). The frequented surface, as calculated by the Minimum Convex Polygon method, are roughly similar all over the study period with respectively $1.121 \mathrm{~km}^{2}$ for Mustela vison and $1.482 \mathrm{~km}^{2}$ for Mustela putorius. Based on monthly surveys, the mean surface of the activity area is estimated at $0.280 \mathrm{~km}^{2}$ per month for mink and $0.296 \mathrm{~km}^{2}$ per month for polecat.

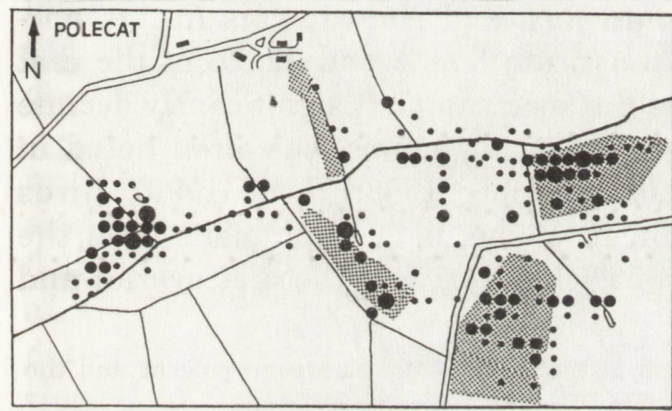

$\because=1, \quad 0: 2$ to 4 ,
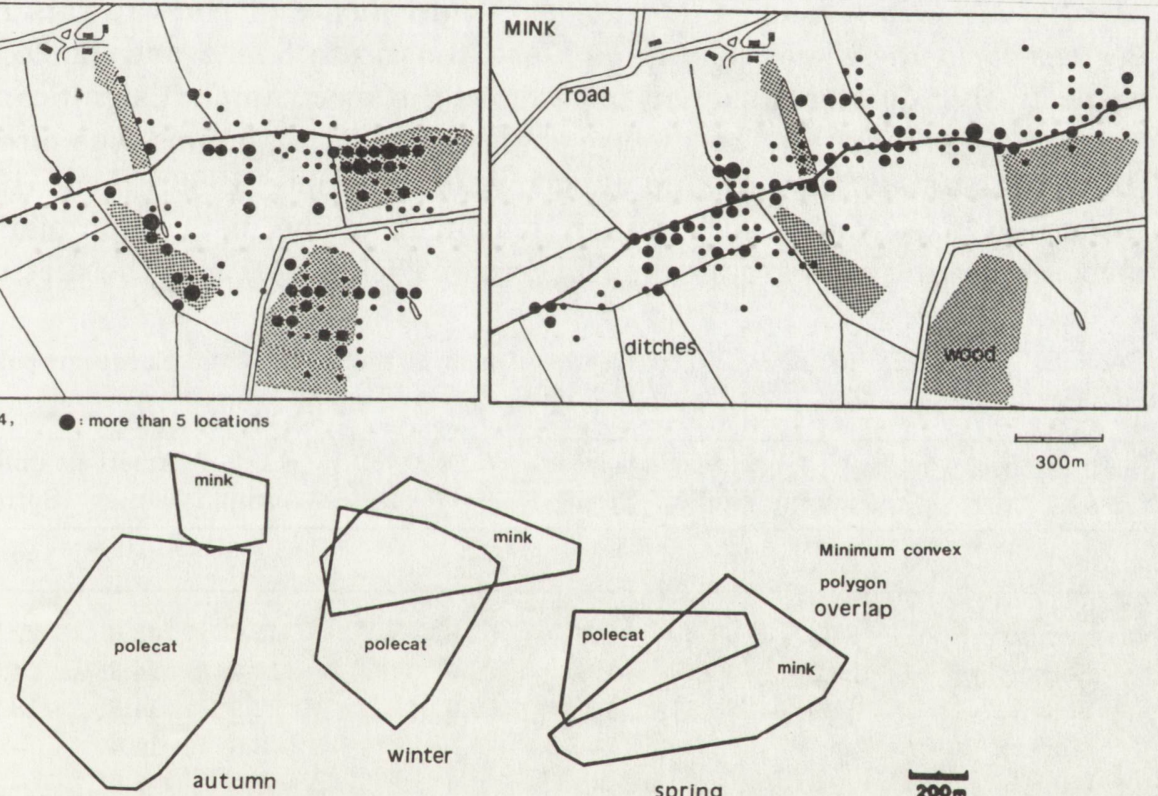

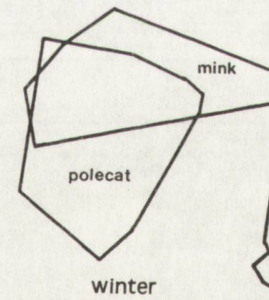

winter

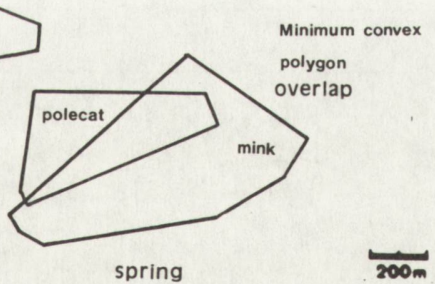

Fig. 1. Movements of male polecat and male mink based on radiotracking between November 1990 and March 1991.

The polecat exploited woodland in autumn and winter but marsh, ditches and ponds in spring $(p<0.01$, Table 1$)$. The mink foraged extensively on marshes with little incursions in woods. Space using by mink largely overlapped with portions of polecat range and $\mathrm{C}_{\mathrm{jk}}=0.61$. But only $8.3 \%$ of fixes $(n=41)$ were recorded on the same square whereas $91.7 \%(n=455)$ were not. Habitat use was significantly different $\left(\chi^{2}=83.14, p<0.001\right)$. Environments were not frequented at the same time, and areas used by the polecat were visited by the mink after a period of several days (minimum 2). 
Table 1. Habitats used by the polecat and the mink, based on percentage of active fixes.

\begin{tabular}{lcccccccc}
\hline & \multicolumn{3}{c}{ European polecat } & \multicolumn{4}{c}{ American mink } \\
& Autumn & Winter & Spring & Total & Autumn & Winter & Spring & Total \\
\hline Woodland & 60.1 & 47.2 & 2.3 & 40.8 & 10.3 & 9.7 & 1.1 & 5.8 \\
Meadow & 18.9 & 9.7 & - & 11.4 & 27.6 & 5.5 & 2.2 & 7.4 \\
Marsh and ditches & 20.9 & 43.1 & 97.7 & 47.8 & 62.1 & 84.7 & 96.6 & 86.6 \\
$n$ & 148 & 72 & 86 & 306 & 29 & 72 & 89 & 190 \\
\hline
\end{tabular}

\section{Dietary composition}

The diet of polecat includes a wide variety of prey species (Table 2). Rodents and amphibians are the dominant prey groups. Of the mammals, voles Microtus arvalis, $M$. agrestis, and Clethrionomys glareolus, and Norway rats Rattus norvegicus form the major food groups and constitute $50.8 \%$ and $22.6 \%$ of the diet respectively. Mammals amount to $82.8 \%$ of the spectrum, but significantly decline in spring $(p<0.001)$. The dietary importance of mammals was often noted in previous studies (Danilov and Rusakov 1969, Weber 1989a, Lodé 1990). Birds (especially passerines) are a minor component of the diet. Amphibians form the most important prey group in spring, comparising $14.1 \%$ of the diet overall and

Table 2. Percentage frequency of occurrences of food in the scats of the European polecat and the American mink.

\begin{tabular}{lcccccccc}
\hline & \multicolumn{3}{c}{ European polecat } & & \multicolumn{4}{c}{ American mink } \\
& Autumn & Winter & Spring & Total & Autumn & Winter & Spring & Total \\
\hline$n$ prey items & 45 & 53 & 30 & 128 & 35 & 35 & 22 & 92 \\
\hline Mammals & 84.4 & 96.2 & 56.7 & 82.8 & 45.7 & 48.6 & 22.7 & 41.3 \\
$\quad$ Norway rat & 22.2 & 30.2 & 10.0 & 22.6 & 11.4 & 14.3 & 4.5 & 10.9 \\
$\quad$ Vole & 48.9 & 54.7 & 46.7 & 50.8 & 22.9 & 14.3 & 18.2 & 18.5 \\
$\quad$ Muskrat & 4.4 & 3.8 & - & 3.1 & 8.6 & 11.4 & - & 7.6 \\
$\quad$ Rabbit & 2.2 & - & - & 0.8 & 2.9 & 2.9 & - & 2.2 \\
$\quad$ Shrew & 6.7 & 7.5 & - & 5.5 & - & 5.7 & - & 2.2 \\
Birds & - & - & 3.3 & 0.8 & 22.9 & 17.1 & 27.3 & 21.7 \\
Amphibians & 13.3 & - & 40.0 & 14.1 & - & - & 18.2 & 4.3 \\
Fish & - & - & - & - & 31.4 & 31.4 & 31.8 & 31.5 \\
$\quad$ Cyprinids & - & - & - & - & 25.7 & 17.1 & 22.7 & 21.7 \\
$\quad$ Eel & - & - & - & - & 2.9 & 2.9 & - & 2.2 \\
$\quad$ Perch & - & - & - & - & 2.9 & 2.9 & 4.5 & 3.3 \\
Other & - & - & - & - & - & 8.6 & 4.5 & 4.3 \\
Invertebrates & 2.2 & 3.8 & - & 2.3 & - & 2.9 & - & 1.1 \\
Index $H^{\prime}=$ & 0.707 & 0.243 & 1.143 & 0.789 & 1.527 & 1.615 & 1.969 & 1.831 \\
\hline & & & & & & & &
\end{tabular}


are even present in autumn. Agile frog Rana dalmatina are the main species taken, but toads Bufo bufo are also eaten. Anuran breeding congregations have been formed in the spring (Matz and Weber 1983) and a synchrony could be noted between the increased incidence in the polecat diet.

Fish are a common prey for mink. Cyprinids (Rutilus rutilus, Scardinus erythrophthalmus, Phoxinus phoxinus, Tinca tinca, Abramis brama, Cyprinus carpio) are commonly taken and their frequency remains approximatively constant. By contrast, in northern Europe, a winter increase of fish frequency was frequently shown (Gerell 1967, Akande 1972, Erlinge 1972, Chanin and Linn 1980, Wise et al. 1981). Eels (Anguilla anguilla) constitute only $2.2 \%$ of the diet. Other fish (Lepomis gibbosus, Ictalurus meles, Esox lucius) form a minor part of the diet of the mink. Amphibians represent only 4.3\% of annual diet. In Sweden (Gerell 1967) and Belarus (Sidorovich 1992) amphibians are a more exploited resource. Birds form an important prey category for mink. Their importance increases in March (29.4\%). Mammals comprise $41.3 \%$ of the diet of the mink and significantly decrease in spring $(p<0.05)$.

Amphibians are of much greater dietary importance to the polecat than to the mink, whereas fish are an important prey group for mink. Dietary niche overlap averages 0.481 over the study period $\left(C_{j k}=0.471\right.$ in autumn, 0.486 in winter, 0.442 in spring). The greatest food overlap concerns the rodents. Jedrzejewski et al. (1969) also noticed that the winter common use of rodents by several carnivores determines the degree of overlapping in the Białowieża Primeval Forest. Polecat clearly avoids competition by preying largely upon anurans in spring and mink reduces competitive interactions by eating fish and birds. Feeding on alternative prey and temporal segregation in space use greatly contribute to limit interspecific competition. In western France, heterogenous habitat supporting a great diversity of prey could allowed the long-term coexistence of these sympatric mustelids.

Acknowledgements: I thank J. Y. Gautier and J. C. Guyomarch (University of Rennes I). D. Le Jacques has provided a precious assistance in collecting data.

\section{References}

Akande M. 1972. The food of feral mink (Mustela vison) in Scotland. J. Zool., Lond. 167: 475 - 479.

Aliev F. and Sanderson G. 1970. The American mink, Mustela vison, in the U.S.S.R. Säugetierk. Mitt. 18: $122-127$.

Camby A., Legall O. and Maizeret C. 1984. Atlas d'identification des restes alimentaires de la loutre. Bull. Gpe. Loutres 16: $1-16$.

Chaline J., Baudvin H., Jammot D. and Saint-Girons M. C. 1974. Les proies des rapaces. Doin, Paris: $1-141$.

Chanin P. R. F. 1981. The diet of the otter and its relation with the feral mink in two areas of S. W. England. Acta theriol. 26: $83-95$.

Chanin P. R. F. and Linn I. 1980. The diet of the feral mink (Mustela vison) in southwest Britain. J. Zool., Lond. 192: $205-223$.

Chanudet F. and Saint-Girons M. C. 1981. Répartition du Vison européen (Mustela lutreola) dans le sud ouest de la France. Ann. Soc. Sc. Nat. Charente Maritime 6: 851 - 858 . 
Danilov P. I. and Rusakov O. S. 1969. Peculiarities of the ecology of Mustela putorius in Nort West districts of the european part of the USSR. Zool. Žh. 48: 1383 - 1394. [In Russian with English summary]

Day M. G. 1966. Identification of hair and feather remains in the gut and faeces of stoats and weasels. J. Zool., Lond. 148: $201-217$.

Debrot S., Fivaz G., Mermod C. and Weber J. M. 1982. Atlas des poils de Mammiferes d'Europe. Inst. Zool. Univ. Neuchâtel: $1-208$.

Dupont P. 1972. La végétation du Parc de Brière. Penn. Ar. Bed. 69: 282 - 295.

Erlinge S. 1972. Interspecific relations between otter, Lutra lutra L., and mink, Mustela vison S. in Sweden. Oikos 23: $327-335$.

Gerell R. 1967. Food selection in relation to habitat in mink (Mustela vison Schreber) in Sweden. Oikos 18: $233-246$.

Jenkins D. and Harper R. J. 1980. Ecology of otters in northern Scotland: analysis of otter (Lutra lutra) and mink (Mustela vison) faeces from Deeside N. E. Scotland in 1977 - 1978. J. Anim. Ecol. 49: $737-754$.

Jędrzejewski W., Jędrzejewska B. and Szymura A. 1989. Food niche overlaps in a winter community of predators in the Białowieża Primeval Forest, Poland. Acta theriol. 34: 487 - 496.

Lodé T. 1990. Le régime alimentaire d'un petit carnivore, le Putois (Mustela putorius) dans l'Ouest de la France. Gibier Faune Sauvage 7: 193 - 203.

Lodé T. 1991a. Exploitation des milieux et organisation de l'espace chez deux mustélidés européens: la Fouine et le Putois. Vie et Milieu 41: 29 - 38.

Lodé T. 1991b. Les déplacements du Vison américain Mustela vison Schreber suivi par radiotracking sur une rivière bretonne. Mammalia 55: 643 - 646 .

Lodé T. 1993. Stratégies d'utilisation de l'espace chez le Putois européen Mustela putorius L. dans l'ouest de la France. Rev. Ecol. Terre et Vie 48. (in press)

Lodé T., Pondaven M. and Le Jacques D. 1990. Note préliminaire sur la biologie du Vison d'Amérique Mustela vison dans l'ouest de la France. Bull. Soc. Sc. Nat. Ouest France 12: $137-140$.

Matz G. and Weber D. 1983. Guide des Amphibiens et Reptiles d'Europe. Delachaux \& Niestlé, Neuchâtel-Paris: $1-292$.

Moors P. J. 1984. Coexistence and interspecific competition in the carnivore genus Mustela. Acta zool. Fenn. 172: $37-40$.

Powell R. A. and Zieliński W. J. 1983. Competition and coexistence in mustelid communities. Acta zool. Fenn. 174: 223 - 227.

Rage J. C. 1974. Batraciens fossiles du quaternaire. Bull. Soc. Linn., Lyon 43: 276 - 289.

Rosenweig M. L. 1966. Community structure in sympatric Carnivora. J. Mammal. 47: 602 -612.

Saint-Girons M. C., Lodé T. and Nicolau-Guillaumet P. 1988. Atlas des Mammiferes terrestres de Loire-Atlantique. M. N. H. N. Paris, 1 - 103.

Schoener T. W. 1971. Theory of feeding strategies. Anim. Rev. Ecol. Syst. 2: $369-404$.

Sidorovich V. E. 1992. Comparative analysis of the diets of European mink (Mustela lutreola), American mink (M. vison), and Polecat (M. putorius) in Byelorussia. Small Carnivora Cons. 6: 2 - 4 .

Weber D. 1989a. The diet of polecats (Mustela putorius L.) in Switzerland. Z. Säugetierkd. 54: 157 - 171.

Weber D. 1989b. Foraging in Polecat (Mustela putorius L.) of Switzerland. The case of a specialist anuran predator. Z. Säugetierkd. 54: $377-392$.

Wise M. H., Linn I. and Kennedy C. R. 1981. A comparison of the feeding biology of mink, Mustela vison, and otter, Lutra lutra. J. Zool., Lond. 195: $181-213$.

Yougman P. M. 1982. Distribution and systematics of the European mink, Mustela lutreola Linnaeus 1761. Acta zool. Fenn. 166: 1 - 48.

Zimmermann F., Gerard H. and Charles-Dominique P. 1976. Le radiotracking des vertébrés: conseils et techniques d'utilisation. Rev. Ecol., Terre et Vie 30: $300-346$. 